\title{
Lisianthus 'UF Savanna' -- Eight Colors of Heat-Tolerant Single-Flowering Cultivars Released by the University of Florida's Lisianthus Breeding Program. ${ }^{1}$
}

Brent K. Harbaugh and Zhanao Deng ${ }^{2}$

In 1985, we began a lisianthus [Eustoma grandiflorum (Raf.) Shinners; Gentianaceae Juss.] breeding program at the University of Florida's Gulf Coast Research and Education Center in Bradenton, Florida. The emphasis was on development of pot or bedding plant types with heat tolerance and basal branching. Cultivars differ significantly in their sensitivity to high temperatures (Fukuda et al., 1994; Harbaugh et al., 1992; Li et al., 2002). Seedlings of most commercial lisianthus cultivars form rosettes (formation of a basal cluster of leaves with no flowering stems) when grown at or above 25 to $28^{\circ} \mathrm{C}$ (Harbaugh et al., 1992; Harbaugh, 1995;

Ohkawa et al., 1991; Ohkawa et al., 1994; Pergola, 1992). 'Maurine Blue' (Harbaugh and Scott, 1996) and 'Florida Blue' (Harbaugh et al, 1996) were the first heat-tolerant lisianthus whose seedlings could be grown at $28-31^{\circ} \mathrm{C}\left(82-88^{\circ} \mathrm{F}\right)$ without rosetting.

'Maurine Blue' was intended to be used as a flowering potted plant when grown with the use of growth retardants or as a bouquet cut flower without growth retardants. Additional colors have been added over the years that also were heat tolerant with vegetative and flower characteristics similar to 'Maurine Blue'. The Maurine cultivar group now includes pink, pink-lilac, white, light blue, lilac (Harbaugh and Scott, 1998), blue/white (Harbaugh and Scott, 2003), and pink/white (Harbaugh and Scott, 2005 a) bi-colored flowers. When grown without growth retardants, these cultivars have a height suitable for the bouquet-cut flower market.

'Florida Blue' was semi-dwarf and intended to be used as a bedding plant. Additional colors added to form the Florida cultivar group included light blue, pink (Harbaugh and Scott, 1999), silver (Harbaugh and Scott, 2001), blue/white and pink/white (Harbaugh and Scott, 2005 b) bi-colored flower colors.

The UF Savanna cultivar group is heat tolerant and intermediate in height between the Florida cultivar group and the Maurine cultivar group. The UF Savanna cultivar group is represented with eight colors including blue, pink, white, silver, blue rim, pink rim, blue frost, and pink frost (Fig. 1). To our knowledge, 'Savanna Blue Frost' and 'Savanna Pink

1. This document is ENH1066, one of a series of the Environmental Horticulture Department, Florida Cooperative Extension Service, Institute of Food and Agricultural Sciences, University of Florida. Original publication date February, 2007. Visit the EDIS Web Site at http://edis.ifas.ufl.edu.

2. Brent K. Harbaugh, professor and Zhanao Deng, assistant professor, Gulf Coast Research and Education Center, Cooperative Extension Services, IFAS, University of Florida, Gainesville, FL 32611

The Institute of Food and Agricultural Sciences (IFAS) is an Equal Opportunity Institution authorized to provide research, educational information and other services only to individuals and institutions that function with non-discrimination with respect to race, creed, color, religion, age, disability, sex, sexual orientation, marital status, national origin, political opinions or affiliations. U.S. Department of Agriculture, Cooperative Extension Service, University of Florida, IFAS, Florida A. \& M. University Cooperative Extension Program, and Boards of County Commissioners Cooperating. Larry Arrington, Dean 
Frost' flower colors are not available in other commercial pot type lisianthus.

\section{Selection Procedures}

Growing conditions used to select seedlings for resistance to heat-induced rosetting during development of heat-tolerant parents included: (1) production during summer months under greenhouse conditions at day temperatures $\geq 35^{\circ} \mathrm{C}$, (2) exposure of 2- to 4-week-old seedlings to $28^{\circ} \mathrm{C}$ for 4 weeks in a growth chamber for initial selections in early generations, and (3) exposure of 17-day-old seedlings to $31^{\circ} \mathrm{C}$ in a growth chamber for 5 weeks for selection of final parents used in $\mathrm{F}_{1}$ hybrids. The photosynthetic photon flux in growth chambers was 150-190 $u \mathrm{~mol} \cdot \mathrm{m}^{-2} \cdot \mathrm{s}^{-1}$ from cool-white fluorescent bulbs.

Heat tolerance vegetative and flower characteristics of the UF Savanna cultivar-group were compared to seven commercial bedding or pot type cultivars. Seeds of all cultivars were planted on 19 January 2005, at Bradenton, Fla.

Seventeen-day-old seedlings were grown either in a glasshouse (control) with a high of 30 to $33^{\circ} \mathrm{C}$ day and 13 to $15^{\circ} \mathrm{C}$ night or at a constant $31^{\circ} \mathrm{C}$ for 5 weeks in a growth chamber (heat-stressed). Seedlings exposed to $31^{\circ} \mathrm{C}$ were rated as rosetted if they had not bolted after growth for an additional 4 weeks in the control greenhouse. Non-rosetted plants from the control greenhouse were evaluated for plant height, plant width, number of branches (lateral stems forming on the central stem from the basal leaves to the first flower), total number of flowers and buds per plant after three flowers were open, petal length, and the number of days from sowing to flowering.

The most important and distinguishing attribute of all the UF Savanna cultivar-group cultivars as compared with other commercial lines was their heat tolerance (Table 1). 'Florida Blue' was an exception but it was released from our program as a semi-dwarf and heat-tolerant line and is now commercialized (Harbaugh et al., 1996). None of the heat-stressed Savanna cultivar group rosetted while $47 \%$ 'Forever Blue', 30\% 'Lisa Blue', 100\% 'Lizzy Blue', 40\% 'Mermaid Blue', 86\% 'Sapphire Blue', and 67\% 'Tiramisu Purple' seedlings rosetted.
In addition to heat tolerance, we considered that the UF Savanna cultivars exhibited sufficient similarities in flower form and display, branching habit, and in the number of days from sowing to flowering to be included in the UF Savanna cultivar-group. Notable differences were that days to flower ranged from 111 to 116 days for all UF Savanna cultivars except 'UF Savanna Pink', which flowered earliest at 108 days; that 'UF Savanna Blue Frost' were very floriferous ( 75 flowers and buds); and that 'UF Savanna Blue', 'UF Savanna Silver' and 'UF Savanna White' had very large petals $(7.2,6.7$ and $6.6 \mathrm{~cm}$, respectively).

\section{Characteristics and Use}

UF Savanna cultivars are intended to be used as flowering potted plants in containers $\geq$ 15-cm-diameter pots. Plant height for Maurine cultivars averaged 75 to $102 \mathrm{~cm}$ (Harbaugh and Scott, 1998) and Florida cultivars 28 to $35 \mathrm{~cm}$ (Harbaugh and Scott, 2001). Thus the UF Savanna cultivars averaging 38 to $48 \mathrm{~cm}$, were intermediate in height. They have a spray-type flower display that is desirable if lisianthus are to be used as a pot plants making height control easier. Treatment with growth retardants is necessary for production of UF Savanna cultivars in $\leq 15$-cm-diameter pots (Harbaugh et al., 1998). Three to four plugs per 15 -cm-diameter pot are recommended for optimal marketing display (Fig. $1)$.

\section{Literature Cited}

Fukuda, Y., K. Ohkawa, K. Kanematsu, and M. Korenga. 1994. Classification of Eustoma grandiflorum (Raf.) Shinn. cultivars on rosette characteristics based on the bolting ratios after a high temperature treatment. J. Jpn. Soc. Hort. Sci. 62:845-856.

Harbaugh, B. K. 1995. Flowering of Eustoma grandiflorum (Raf.) Shinn. cultivars influenced by photoperiod and temperature. HortScience 30:1375-1377.

Harbaugh, B. K., R. J. McGovern, and J. F. Price. 1998. Potted lisianthus: Secrets of success.

Greenhouse Grower 16(1):42, 44, 46, 48, 50, 52. 
Harbaugh, B. K., M. S. Roh, R. H. Lawson, and B. Pemberton. 1992. Rosetting of lisianthus cultivars exposed to high temperatures. HortScience 27:885-887.

Harbaugh, B. K. and J. W. Scott. 1996. 'Maurine Blue' lisianthus [Eustoma grandiflorum (Raf.) Shinn.]. HortScience 31:1055-1056.

Harbaugh, B. K. and J. W. Scott. 1998. Six heat-tolerant cultivars of lisianthus. HortScience 33:164-165.

Harbaugh, B. K. and J. W. Scott. 1999. 'Florida Pink' and 'Florida Light Blue' - Semi-dwarf heat-tolerant cultivars of lisianthus. HortScience 34:364-365.

Harbaugh, B. K. and J. W. Scott. 2001. 'Florida Silver' - A semi-dwarf heat-tolerant lisianthus. HortScience 36:988-989.

Harbaugh, B. K. and J. W. Scott. 2003. 'Maurine Twilight' and 'Maurine Daylight' Heat-tolerant lisianthus with bi-colored flowers. HortScience 38:131-132.

Harbaugh, B. K. and J. W. Scott. 2005 a. 'Maurine Dawn'-A heat-tolerant lisianthus with pink/white bicolored flowers. HortScience 40:858-860.

Harbaugh, B. K. and J. W. Scott. 2005 b. Florida Blue Frill and Florida Pink Frill-Semi-dwarf heat-tolerant lisianthus with bicolored flowers. HortScience 40:861-863.

Harbaugh, B. K., J. W. Scott, and D. B. Rubino. 1996. 'Florida Blue' semi-dwarf lisianthus [Eustoma grandiflorum (Raf.) Shinn.]. HortScience 31:1057-1058.

Li, J., Y. Notsu, M. Ogawa, H. Ohno, and K. Ohkawa. 2002. Rosetting characteristics-based on classification of Eustoma grandiflorum (Raf.) Shinn. cultivars sown on different dates. (Japanese text with English abstract) Environ. Control in Biol. 40:229-237.

Ohkawa, K., A. Kano, K. Kanematsu, and M. Korenaga. 1991. Effects of air temperature and time on rosette formation in seedlings of Eustoma grandiflorum (Raf.) Shinn. Scientia Hort. 48:171-176.

Ohkawa, K., T. Yoshizumi, M. Korenaga, and K. Kanematsu. 1994. Reversal of heat-induced rosetting in Eustoma grandiflorum with low temperatures. HortScience 29:165-166.

Pergola, G. 1992. The need for vernalization in Eustoma russellianum. Scientia Hort. 51:123-127.

Royal Horticultural Society. 1966. Royal Horticultural Society colour chart. Royal Hort. Soc., London. 


\section{'UF SAVANNA' Series}

\section{Lisianthus}

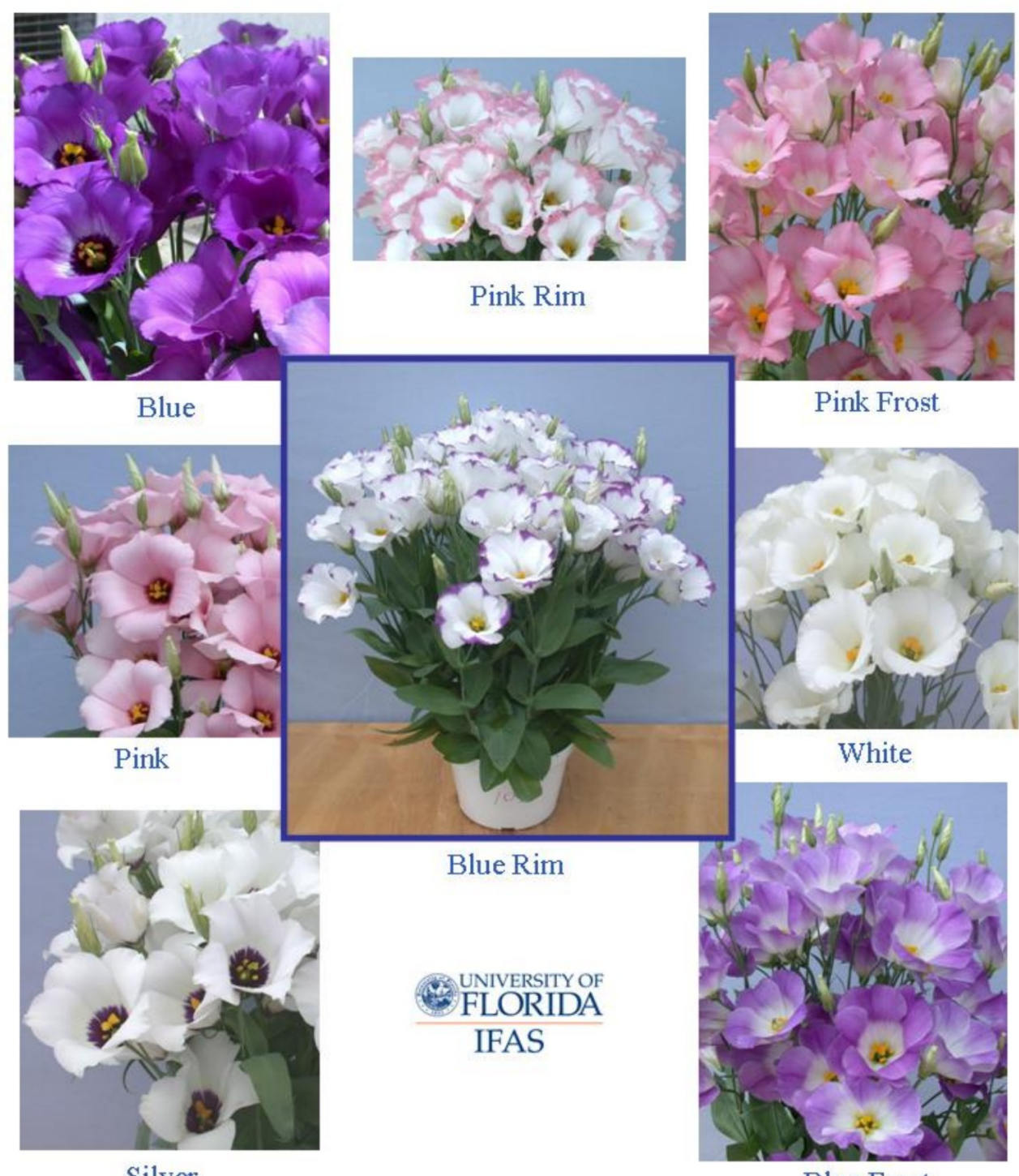

Blue Frost 
Table 1. Percentage rosetted plants ${ }^{z}$ and growth and flowering characteristics ${ }^{y}$ of twelve lisianthus cultivars grown in 11.5 -square-cm pots (0.65-L) at Bradenton, Florida.

\begin{tabular}{|c|c|c|c|c|c|c|c|}
\hline \multirow[b]{2}{*}{ Cultivar } & \multicolumn{4}{|c|}{ Plant $^{x}$} & \multirow{2}{*}{$\begin{array}{c}\text { Flowers } \\
\text { and buds } \\
\text { (no.) }\end{array}$} & \multirow{2}{*}{$\begin{array}{l}\text { Petal } \\
\text { length } \\
(\mathrm{cm}) \\
\end{array}$} & \multirow{2}{*}{$\begin{array}{c}\text { Days to } \\
\text { flower } \\
\text { (no.) }\end{array}$} \\
\hline & $\begin{array}{c}\text { Rosetted } \\
(\%) \\
\end{array}$ & $\begin{array}{c}\mathrm{ht} \\
(\mathrm{cm}) \\
\end{array}$ & $\begin{array}{l}\text { width } \\
\text { (cm) }\end{array}$ & $\begin{array}{c}\text { Branches }^{\mathrm{w}} \\
\text { (no.) }\end{array}$ & & & \\
\hline Florida Blue & 0 & 36 & 21 & 9 & 63 & 6.3 & 115 \\
\hline Forever Blue & 47 & 32 & 25 & 14 & 62 & 5.1 & 109 \\
\hline Lisa Blue & 30 & 23 & 15 & 7 & 33 & 5.0 & 108 \\
\hline Lizzy Blue & 100 & 28 & 17 & 7 & 49 & 5.9 & 116 \\
\hline Mermaid Blue & 40 & 24 & 18 & 10 & 59 & 5.6 & 112 \\
\hline Sapphire Blue & 86 & 25 & 23 & 11 & 49 & 5.6 & 107 \\
\hline Tiramisu Purple & 67 & 37 & 23 & 14 & 70 & 4.9 & 111 \\
\hline UF Savanna Blue & 0 & 40 & 24 & 10 & 75 & 7.2 & 113 \\
\hline UF Savanna Blue Frost & 0 & 45 & 22 & 12 & 75 & 6.3 & 114 \\
\hline UF Savanna Blue Rim & 0 & 40 & 18 & 9 & 47 & 6.1 & 113 \\
\hline UF Savanna Pink & 0 & 38 & 20 & 8 & 60 & 6.0 & 108 \\
\hline UF Savanna Pink Frost & 0 & 47 & 22 & 8 & 69 & 6.3 & 113 \\
\hline UF Savanna Pink Rim & 0 & 43 & 18 & 7 & 59 & 6.1 & 116 \\
\hline UF Savanna Silver & 0 & 41 & 22 & 10 & 65 & 6.7 & 114 \\
\hline UF Savanna White & 0 & 48 & 19 & 9 & 58 & 6.6 & 111 \\
\hline $\operatorname{LSD}(P=0.05)$ & 25 & 4.6 & 3.0 & 2.2 & 11.6 & 0.4 & 1.7 \\
\hline \multicolumn{8}{|c|}{$\begin{array}{l}{ }^{2} \text { Seventeen-day-old seedling were exposed to } 31^{\circ} \mathrm{C} \text { for } 5 \text { weeks in a growth chamber and then grown in a } \\
\text { greenhouse for } 4 \text { weeks. Percentages of rosetted plants are means of three replications with eight plants as the } \\
\text { experimental unit arranged in a randomized block design. } \\
{ }^{y} \text { Vegetative and flowering characteristics were for plants grown in a greenhouse at } 33 \text { to } 35^{\circ} \mathrm{C} \text { day and } 13 \text { to } 15^{\circ} \mathrm{C} \\
\text { night. values are means of five replications of single-plant experimental units arranged in a completely randomized } \\
\text { design. } \\
{ }^{{ }^{2}} \text { Plant height = distance from the pot rim to the tip of the highests bud measured after three flowers had opened. } \\
\text { w Lateral stems forming on the central stem from the basal leaves to the first flower. }\end{array}$} \\
\hline
\end{tabular}

